\title{
En forvirret nybakt mor
}

\author{
En 30 år gammel kvinne ble etter fødsel i økende grad forvirret, des- \\ orientert og agitert. Ektemannen kontaktet legevakten, og det endte \\ med at hun ble tvangsinnlagt i akuttpsykiatrisk avdeling. På tross av \\ antipsykotisk medikasjon i adekvate doser ble hennes tilstand forverret \\ dag for dag.
}

Se kommentar side 170

\author{
Harald Brauer* \\ harald.brauer@aus.no \\ Klinikk for psykisk helse \\ Oslo universitetssykehus, Aker \\ Egil W. Martinsen \\ Klinikk for psykisk helse og avhengighet \\ Oslo universitetssykehus, Aker \\ og \\ Institutt for klinisk medisin \\ Universitetet i Oslo \\ * Nåværende adresse: \\ Avdeling akuttpsykiatri \\ Akershus universitetssykehus
}

Pasienten er en ung kvinne, som fikk psykiske plager to uker etter at hun hadde født sitt første barn. Hun opplevde fødselen som dramatisk. Det var planlagt vaginal forløsning, men på grunn av langsom fremgang ble det utført keisersnitt. Hun hadde på forhånd vært redd for at dette skulle skje, da hun tidligere hadde hatt ubehagelige opplevelser under narkose. Fødselen gikk imidlertid bra, barnet var friskt og pasienten ble utskrevet til hjemmet etter noen dager.

Vanskelighetene startet etter at hun kom hjem. Hun sov dårlig, kun 2-3 timer per natt den siste uken før innleggelsen. Våketiden om natten ble brukt til å rydde. Hun oppførte seg påfallende og ble $i$ økende grad opptatt av ulike ideer som hun kunne tjene penger på. Hun mistet interessen for barnet, begynte å snakke i gåter og klassifiserte ting ut fra farger. Hun brukte gule post-it-lapper på ting som for henne var gule. Babyen klassifiserte hun som blå, mens rød var en annen viktig farge. Hun ble redd rødfargen, og sa at den forfulgte henne. Mannen opplevde situasjonen som uholdbar og kontaktet lege 14 dager etter fødselen. Legen vurderte at pasienten var psykotisk og at innleggelse var nødvendig. Det lyktes ikke å motivere henne for frivillig innleggelse, og hun ble tvangsinnlagt. Grunnlaget for dette var at pasienten hadde en alvorlig sinnslidelse, og at hun uten innleggelse ville få sin utsikt til helbredelse eller bedring vesentlig redusert. Ved innleggelsen snakket hun usammenhengende og assosierte livlig. Hun var agitert og oppstemt, og hadde ingen sykdomsfølelse. Hun trodde innleggelsen skyldtes et spesielt tall. Det var normale funn ved somatisk undersøkelse og orienterende blodprøver. Det var ingen holdepunkter for at pasienten hadde misbrukt alkohol eller narkotika.

Tilstanden ble initialt vurdert som en akutt psykose med utpreget forvirring. De vanlige behandlingsprinsipper med antipsykotiske medikamenter og miljøterapeutiske tiltak med tett oppfølging og skjerming ble iverksatt.

På avdelingen ble hennes tilstand dramatisk forverret i løpet av få døgn. Hun var motorisk urolig, gikk rundt og plukket på ting, slo av og på brytere, og forsøkte en rekke ganger å gå inn på andre pasienters rom. Hun var desorientert og forvirret og overbevist om at hun arbeidet på avdelingen og at personalet var hennes ansatte. På grunn av sin atferd ble hun skjermet på eget avsnitt med tett oppfølging.

Pasienten ble gitt antipsykotisk medikasjon dagen etter innleggelsen og fikk antipsykotiske medikamenter i høye doser over flere dager: olanzapin peroralt opptil $30 \mathrm{mg}$ daglig, og zuklopentixol som injeksjon intramuskulært $100 \mathrm{mg}$ gitt ved to anledninger. Hun responderte ikke på denne behandlingen.

Da hun knapt hadde sovet på mange dager, håpet vi at langvarig søvn skulle dempe plagene hennes. Hun fikk derfor store doser diazepam peroralt, opptil $60 \mathrm{mg}$ per døgn, dosert med $10 \mathrm{mg}$ i timen inntil søvn, i tillegg til fortsatt antipsykotisk medikasjon. Pasienten falt i dyp søvn etter seks timer og hadde da fått til sammen $60 \mathrm{mg}$ diazepam. Hun sov i 12-14 timer, men var like forvirret da hun våknet opp igjen. Hun ble dårligere dag for dag. Talen ble mer og mer usam- menhengende. Hun var ikke i stand til å holde seg på rommet, og da hun ble bedt om å gå tilbake, slo og sparket hun etter personalet. Da alle andre alternativer var fors $\emptyset$ kt, ble pasienten fiksert i belteseng tre dager etter innleggelsen.

Behandlingsforsøket rettet mot hennes psykotiske tilstand hadde åpenbart ikke hatt noen effekt, og vi var usikre på hvorfor medikamentene ikke hadde hjulpet. Pasienten var ikke i stand til å gi pålitelige opplysninger om sin tidligere sykehistorie, så komparentopplysninger fra pasientens ektemann og foreldre ble viktige.

Ektemannen fortalte at hun hadde hatt en alvorlig depresjon noen år tidligere. I forbindelse med dette hadde hun vært innlagt ett døgn i medisinsk avdeling etter en selvpåført intoksikasjon med tabletter. Deretter ble hun fulgt opp på psykiatrisk poliklinikk og brukte antidepressive medikamenter $i$ form av citalopram i et halvt år. Forut for depresjonen hadde pasienten vært på ferie. Der hadde hun vært mer sosial og utadvendt enn hun pleide. Hun hadde brukt mye penger og måtte ha økonomisk bistand fra sine foreldre for å betale gjelden etter ferien. Utover disse to episodene, hadde pasienten ikke vært psykisk syk. Hun var en forsiktig person som hadde orden på økonomien.

Opplysningene fra pårørende tydet på at hun hadde hatt en hypoman episode etterfulgt av en alvorlig depresjon, noe som er forenlig med bipolar lidelse (1). I lys av dette kunne hennes nåværende tilstand klassifiseres som en manisk episode med psykotiske symptomer, som ledd i en bipolar lidelse, med debut post partum. Ved denne tilstanden er elektrokonvulsiv behandling (ECT) anbefalt i norsk og internasjonal faglitteratur (2-4), men helsemyndighetene har ikke utarbeidet retninglinjer for dette.

Hennes tilstand var alvorlig, og hun var ikke lenger kompetent til å gi informert samtykke. Det var ikke mulig for oss å bedømme om hun var i stand til å ta imot informasjon om elektrokonvulsiv behandling og om hun ønsket behandlingen eller ikke. Etter grundig informasjon fra behandler ønsket hennes nærmeste pårørende, ektemann og foreldre, at hun skulle få denne behandlingen.

Dette var en situasjon med store utfordringer både psykiatrisk, etisk og juridisk. Vi drøftet disse problemstillingene nøye med spe- 


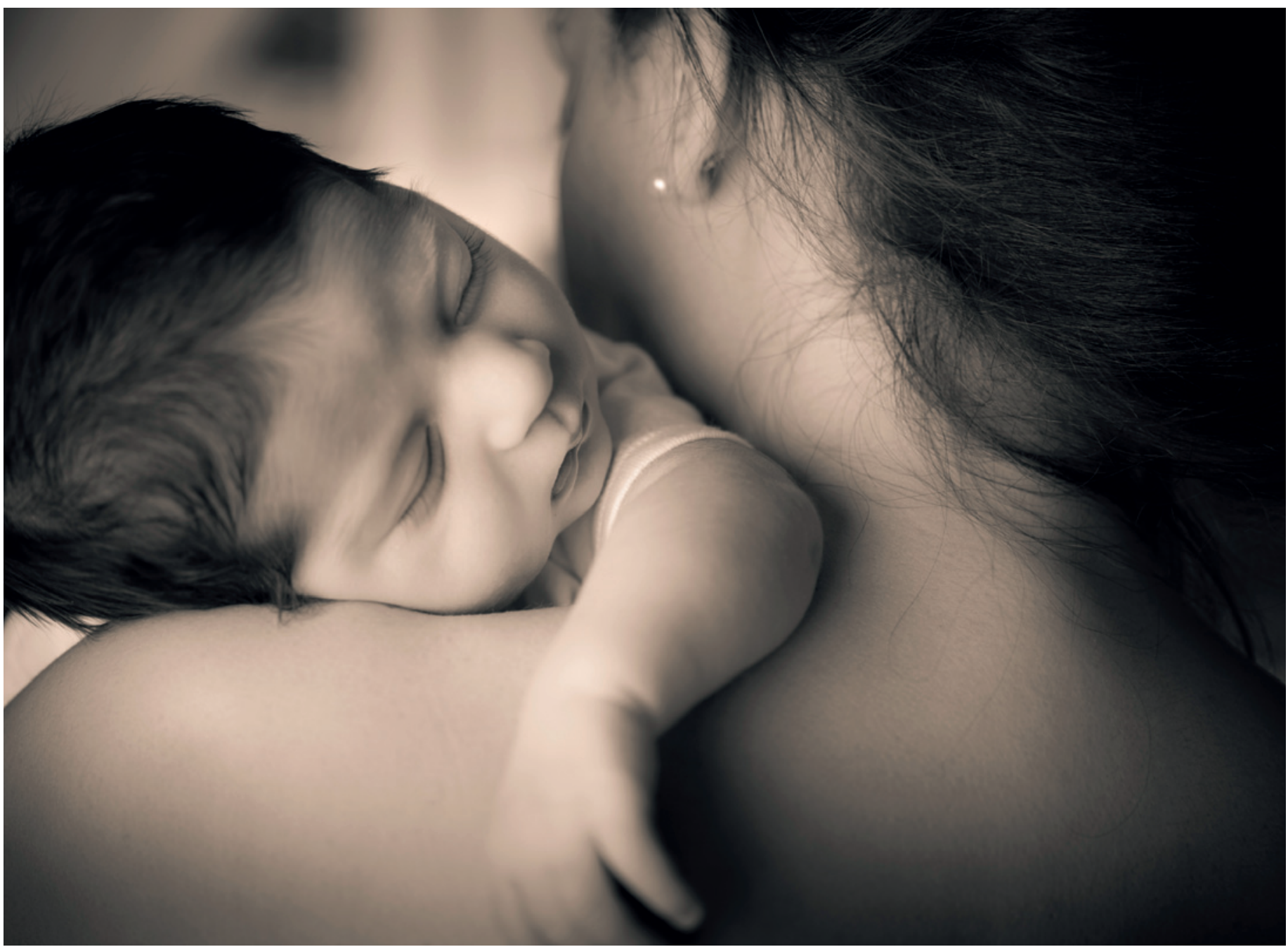

Illustrasjonsfoto Istockphoto

sialistene ved vår avdeling, overlegen ved anestesiavdelingen og klinisk etikkomité på sykehuset. Vi kontaktet også helseavdelingen ved Fylkesmannens kontor for å få en avklaring omkring det juridiske aspektet ved å gi elektrokonvulsiv behandling til en tvangsinnlagt pasient som lå i belter. I klinisk etikkkomité var det enighet om at det ville være forsvarlig å gi pasienten slik terapi uten pasientens samtykke, da det er en anerkjent psykiatrisk behandlingsmetode. Fylkeslegen motsatte seg ikke at pasienten fikk denne behandlingen uten samtykke, som ledd $i$ en nødrettsvurdering.

To uker etter at pasienten ble innlagt startet den elektrokonvulsive behandlingen. Behandlingen måtte foregå på belterommet på skjermet enhet. Pasienten ble fiksert $i$ belter mens narkosen ble gitt, og beltene ble løsnet under selve behandlingen. Effekten var overveldende, og allerede noen timer etter den første behandlingen klarnet hun opp. Nødrettsvurderingene ble fortløpende nedfelt i pasientens journal. Samtykke ble innhentet av pasienten dagen etter behandlingsstart.

Elektrokonvulsiv behandling gis vanligvis 2-3 ganger per uke. Hun fikk seks be- handlinger i løpet av to uker, og de psykotiske symptomene forsvant. Bortsett fra noe redusert korttidshukommelse hadde hun ingen bivirkninger. Etter tre behandlinger ble tvunget psykisk helsevern opphevet, og hun ble overflyttet til en åpen avdeling. Etter gjennomført behandling kunne hun få permisjoner til hjemmet og ta ansvar for barnet sitt. Pasienten ble utskrevet etter 11 uker og ble deretter fulgt opp regelmessig av psykiater ved poliklinikken.

For å hindre tilbakefall fikk hun forebyggende behandling med litium og olanzapin tabletter. Hun ble anbefalt å bruke litium i flere år, mens olanzapin gradvis ble nedtrappet og seponert. En måned etter utskrivningen fra akuttavdelingen fikk hun depressive symptomer i form av nedstemthet, indre uro, lav selvfølelse og selvmordstanker. Hun fikk da escitalopram i tillegg til litium.

Siden hun hadde vært alvorlig syk og ikke hadde hatt kontakt med barnet sitt på mer enn to uker, var hun svært usikker i sin rolle som mor. Dette ble forsterket av at hun hadde redusert korttidshukommelse etter den elektrokonvulsive behandlingen. Mor og barn ble derfor henvist til barnepsykiatrisk poliklinikk for å bedre samspillet. Pasienten hadde vansker med å være følelsesmessig til stede i sitt forhold til barnet og slet med å svare adekvat på barnets signaler. Allerede etter noen uker var samspillet bedre. Etter ni måneder ble forholdet mellom mor og barn vurdert å være normalt, og kontakten med barnepsykiatrisk poliklinikk ble avsluttet.

Pasienten husket svært lite fra de første ukene av innleggelsen. Fremdeles hadde hun noen hukommelsesvansker knyttet til praktiske gjøremål $i$ hverdagen. Tre måneder etter utskrivningen begynte hun på jobb i $80 \%$ stilling. Barnet gikk i barnehage. Et halvt år senere var hun tilbake i full jobb, og ved vår siste kontakt 15 måneder etter innleggelsen var hun frisk og hadde ikke hatt tegn til tilbakefall.

\section{Diskusjon}

Ved alle alvorlige psykiske symptomer kort tid etter fødsel bør man vurdere mulig affektiv lidelse, selv om sykdomsbildet kan være annerledes enn det man vanligvis ser ved slike lidelser. Sykehistorien er helt essensiell i all diagnostikk, og komparentopplysninger er sentrale, særlig når pasienten selv ikke er i stand til å forklare seg. Rundt $80-85 \%$ av 
postpartumpsykoser er av affektiv natur, hovedsakelig relatert til bipolar lidelse (2). Dette burde ha vært arbeidshypotesen ved innleggelsen.

Ved bipolar lidelse er arvelige faktorer viktige, og førstegradsslektninger av personer med bipolar lidelse har opptil $20 \%$ risiko for å utvikle postpartumpsykose $(5,6)$. For kvinner med ubehandlet bipolar lidelse har forekomsten av slike psykoser vært rapportert å være $25-50 \%(5,6)$ ved hver fødsel, mens forekomsten i befolkningen er 1-2 per 1000 fødsler $(2,5,6)$. Hos kvinner med bipolar lidelse kan risikoen for postpartumpsykose reduseres til ca. $10 \%$ ved litiumprofylakse under og etter svangerskapet (7).

De fleste blir syke i løpet av de første seks ukene etter nedkomst. Symptomene kan starte brått og være dramatiske. Vanligst er søvnløshet, angst, forvirring, sterk uro, oppstemthet, vrangforestillinger og syns- og hørselshallusinasjoner. Suicidale impulser er ikke uvanlig, og alvorlige aggressive impulser overfor barnet kan forekomme $(6$, $8,9)$. Det er økt risiko for selvmord hele det første året etter forløsningen hos kvinner som har hatt alvorlig psykisk lidelse i postpartumperioden (10).

Ved postpartumpsykose kan elektrokonvulsiv behandling være et godt alternativ når annen behandling ikke fører frem $(2-4,11)$. Noen klinikere mener at slik terapi har en spesifikk effekt ved postpartumpsykose (3, 11), men dette synspunktet har ikke fått gjennomslag i internasjonale behandlingsveiledere $(12,13)$. Det er effektivt, virker ofte raskt og kan kombineres med amming. Effekten av kan være kortvarig, og behandlingen skal følges opp med medikamentell vedlikeholdsbehandling for å forebygge tilbakefall. Her er litium et godt valg (14), men andre stemningsstabiliserende medikamenter kan også brukes. Amming anbefales ikke under litiumbehandling. Uten vedlikeholdsbehandling med medikamenter er det stor fare for tilbakefall etter elektrokonvulsiv behandling (14)

Seponering av litium før planlagt graviditet medfører en betydelig økt risiko for tilbakefall, og i postpartumperioden er det størst risiko. Over halvparten av de som seponerer litium, får tilbakefall i løpet av det første året (15).

Enkelte pasienter sliter med ettervirkninger av elektrokonvulsiv behandling i form av hukommelsesproblemer. Det er vanskelig å forutsi hvem som får dette, men det er godt dokumentert at det er av stor betydning hvordan behandlingen gjennomføres. Bitemporal elektrodeplassering, hyppige og mange behandlinger med stor stimulusdose og pulsvidde, samt sinusbølger, øker risikoen for nedsatt hukommelse (16).

Ifølge lov om psykisk helsevern, § 4-4, om behandling uten eget samtykke, kan det ikke gjennomføres behandling som innebærer et alvorlig inngrep overfor pasientene, med unntak av medisiner og ernæringstilførsel til personer med alvorlig spiseforstyrrelse. I forarbeidene til lov om psykisk helsevern presiseres det at nødrett kan komme inn som eget grunnlag for å gi elektrokonvulsiv behandling uten pasientens samtykke, dersom det er fare for pasientens liv eller at vedkommende kan få alvorlig helseskade (17). Det vises til straffeloven $\S 47$. Elektrokonvulsiv behandling kan ikke gis som tvangsbehandling, men kun iverksettes ut fra nødrettsbetraktninger. Når den akutte nødrettssituasjonen opphører, må tiltak som er iverksatt etter nødrettsbetraktninger, opphøre. Krav til samtykke avhenger av pasientens tilstand, og en pasients evne til å gi samtykke må vurderes ut fra dette. Et svært viktig aspekt er evnen til å oppfatte informasjonen om egen sykdom og situasjon og å kunne resonnere og bruke informasjonen $i$ en avveining av behandlingsalternativer. Pasienter som er tvangsinnlagt mister ikke automatisk evnen til å gi samtykke, men noen pasienter er så dårlige at de midlertidig kan miste evnen til å gi informert samtykke, slik det var tilfellet med vår pasient. Dette bør ikke medføre at de går glipp av nødvendig behandling. Det er et paradoks at loven krever et skriftlig samtykke for å gi elektrokonvulsiv behandling til alvorlig syke pasienter som ikke har evne til å gi dette. Det er bare medikamenter som kan gis uten samtykke, selv om disse også kan ha betydelige bivirkninger.

Vurdert i ettertid ser vi flere forhold som vi ikke håndterte optimalt. Det tok lang tid før pasienten fikk korrekt diagnose og optimal behandling. Ved alvorlige psykiske symptomer i perioden etter fødsel bør man alltid vurdere om det kan foreligge en alvorlig affektiv lidelse, og elektrokonvulsiv behandling bør vurderes.

\section{Harald Brauer (f. 1969)}

er spesialist i psykiatri og avdelingsoverlege ved Avdeling akuttpsykiatri, Akershus universitetssykehus.

Ingen oppgitte interessekonflikter.

\section{Egil W. Martinsen (f. 1950)}

er overlege ved Klinikk for psykisk helse, Oslo universitetssykehus, Aker og professor i psykiatri ved Universitetet i Oslo.

Ingen oppgitte interessekonflikter.
Litteratur

1. WHO. ICD-10. Psykiske lidelser og atferdsforstyrrelser, kliniske beskrivelser og diagnostiske retningslinjer. Oslo: Universitetsforlaget, 1999: $112-6$.

2. Bratfos 0 , Haug JO. Puerperal mental disorders in manic-depressive females. Acta Psychiatr Scand 1966; 42: 285-94

3. Reed P. Sermin N. Appleby L et al. A comparison of clinical response to electroconvulsive therapy in puerperal and non-puerperal psychoses. J Affect Disord 1999; 54: 255-60

4. Berle $\mathrm{J} \emptyset$. Alvorlig depresjon og psykose post partum - når bør elektrokonvulsiv behandling brukes? Tidsskr Nor Lægeforen 1999; 119: 3000-3.

5. Berle $\downarrow \emptyset$, Spigset 0 . Behandling av svangerskaps relatert psykisk sykdom. Tidsskr Nor Laegeforen 2003; 123: 2037-40.

6. Brockington I. Motherhood and mental health. Oxford: Oxford University Press, 1996.

7. Stewart DE, Klompenhouwer JL, Kendell RE et al. Prophylactic lithium in puerperal psychosis. The experience of three centres. Br J Psychiatry 1991; 158: $393-7$

8. d'Orbán PT. Women who kill their children. Br J Psychiatry 1979; 134: 560-71

9. Appleby L, Mortensen PB, Faragher EB. Suicide and other causes of mortality after post-partum psychiatric admission. Br J Psychiatry 1998; 173 : 209-11.

10. Lindahl V, Pearson JL, Colpe L. Prevalence of suicidality during pregnancy and the postpartum. Arch Women Ment Health 2005; 8: 77-87.

11. Efficacy and safety of electroconvulsive therapy in depressive disorders: a systematic review and meta-analysis. Lancet 2003; 361: 799-808.

12. Hales RE, Yudofsky SC, Gabbard GO. Textbook of psychiatry, 5. utg. Washington, DC, American Psychiatric Publishing: 2008.

13. National Institute for Health and Clinical Excellence. Bipolar disorder. NICE clinical guideline 38: 2006

14. Sackeim HA, Haskett RF, Mulsant BH et al. Continuation pharmacotherapy in the prevention of relapse following electroconvulsive therapy: a randomized controlled trial. JAMA 2001; 285 : 1299-307.

15. Viguera AC, Nonacs R, Cohen LS et al. Risk of recurrence of bipolar disorder in pregnant and nonpregnant women after discontinuing lithium maintenance. Am J Psychiatry 2000: 157: 179-84.

16. Sackeim HA, Prudic J, Fuller R et al. The cognitibs effects of electroconvulsive therapy in community settings. Neuropsychopharmacology 2007; 32: 244-54.

17. Ot.prp. nr 11(1998-99). Om lov om etablering og gjennomføring av psykisk helsevern (psykiatriloven).

Mottatt 2.12. 2009, første revisjon innsendt 27.5. 2010, godkjent 1.9. 2011. Medisinsk redaktør Mette Sagsveen. 